\title{
Franklinothrips; a pantropical Thysanoptera genus of ant-mimicking obligate predators (Aeolothripidae)
}

\author{
LAURENCE A. MOUND ${ }^{1} \&$ PHILIPPE REYNAUD ${ }^{2}$ \\ ${ }^{1}$ CSIRO Entomology, GPO Box 1700, Canberra ACT, Australia 2601 \\ ${ }^{2}$ Laboratoire National de la Protection des Végétaux, Unité d'entomologie, 2 Place Viala \\ F-34060 Montpellier cedex 01, France
}

\begin{abstract}
The Aeolothripidae genus Franklinothrips Back is redefined with a key provided to the 14 species recognised worldwide, of which $F$. brunneicornis from New Caledonia and $F$. strasseni from Nepal are described as new. Most of the species appear to be bisexual and localised in distribution, but $F$. vespiformis is usually unisexual and is found in many tropical countries, here being recorded from Australia for the first time. All of the species are probably predatory, as adults and larvae, three species having been promoted as biological control agents against pest thrips in European greenhouses. Comments are given on predation and ant-mimicry amongst Aeolothripidae.
\end{abstract}

Key words: biocontrol, mimicry, predation, new species

\section{Introduction}

The fast-running females of the tropical genus Franklinothrips are, when alive, easily misidentified as ants or bethylid wasps rather than as Thysanoptera (Fig. 1). In this genus, adults as well as their curious red, humped-backed larvae (Fig. 2) are obligate predators on other small arthropods, and they can be observed to actively seek their prey (Hoddle, 2003a,b). The degree of mimicry attained, involving both behaviour and body form, varies between species, and is particularly strong in the African species F. megalops. Males are less ant-like in appearance, being smaller than females, with longer antennae, a less constricted waist, and commonly with paler wings but darker antennae. Some species in the genus appear to be arboreal, living on the leaves of trees and possibly high in the canopy. Other species occur on small trees and shrubs, and $F$. vespiformis is commonly found at ground level on herbs. Various members of the genus are considered to be, and are sometimes marketed as, useful biological control agents against pest thrips (Loomans \& Heij- 
boer, 1999; Loomans \& Vierbergen, 1999). Because of this economic, even commercial interest, the following notes have been prepared concerning the recognition and distribution of the 14 known species.

\section{Ant-mimicry amongst Aeolothripidae}

Ant-mimicry in body form and behaviour has arisen independently several times amongst the various genera of Aeolothripidae. Within the large genus Aeolothrips, ground-living species such as A. albicinctus in Europe and A. bicolor in North America are ant-like in behaviour, and have the first abdominal segment constricted and more-or-less transversely striate, thus producing the appearance of a hymenopteran waist or petiole. Similar habits and striate first abdominal segment occur in the Australian species, Desmothrips reedi, out of 14 known species in the genus Desmothrips (Mound \& Marullo, 1998). These apomorphies are so striking that they have led to most species in the genus Aeolothrips being allocated to a genus Coleothrips (Bhatti, 1990). Ant-like appearance in some Franklinothrips species is similarly achieved through the basal abdominal segments being constricted and sharply white in contrast to the dark brown of the rest of the body. Moreover, this body form has evolved independently in two other genera of ant-mimicking Aeolothripidae: Allelothrips with 7 species from Africa and India, and Stomatothrips with 8 species from the Americas. Unlike Franklinothrips species, members of these two genera are usually found at ground level at the base of grasses, where they are presumably obligate predators on the numerous mites with which they are found. In all of these taxa the most important element involved in the ant-mimicry is the behaviour of the adult females, many having been observed to run very actively and to palpate the substrate with their antennae. Unfortunately, few rigorous behavioural studies have been published on these thrips, most observations being anecdotal.

Mimicry is not the only response by Aeolothripidae to the presence of ants. All species in this family pupate at ground level, and thus these immature stages are vulnerable to ant predation. However, these thrips spin a silken cocoon within which to pupate (Hoddle et al., 2001a), and this cocoon appears to be tough enough to prevent attack by many potential ant predators. Cocoon spinning is possibly a plesiotypic habit amongst terebrantian Thysanoptera, because it also occurs amongst species of Heterothripidae (Pinent et al., 2002).

\section{Predation amongst Aeolothripidae}

Franklinothrips is a member of the Aeolothripidae, a Thysanoptera family that comprises over 190 species in 23 genera worldwide (Mound, 2002). Of these species, 50\% are placed in the Holarctic genus Aeolothrips, and only three genera include more than 10 species-Desmothrips from Australia with 14, Erythrothrips from the western parts of North and South America with 12, and the pantropical Franklinothrips. Members of the first three of these four genera are essentially flower-living, although as indicated above a few 
species in Aeolothrips and Desmothrips live at ground level as obligate predators on mites (Mound \& Marrulo, 1998). The typical flower-living Aeolothrips species are facultative predators rather than obligate predators, and for these species plant tissues constitute an important dietary element (Bournier et al., 1978, 1979). Indeed, Zegula et al. (2003) indicate that Aeolothrips intermedius cannot breed successfully on a diet solely of thrips larvae. In contrast, Franklinothrips is one of several genera of Aeolothripidae in which the species are probably all obligate predators on other small arthropods. F. orizabensis is known to be unable to survive on plant food alone (Hoddle et al., 2001b), but detailed observations are lacking for most species.

In California, F. orizabensis is a useful predator of a thrips pest on avocado trees, and has been the subject of extensive research (Hoddle et al., 2001a,b; Hoddle 2003a,b). Both this species and $F$. vespiformis have been marketed in Europe as biocontrol agents against thrips in greenhouses. In Okinawa, Japan, Araraki and Okajima (1998) found the larvae and adults of $F$. vespiformis preying on the pest species, Thrips palmi, on several vegetable crops. Moreover, when the thrips were cultured on potted plants these authors demonstrated that the predator would also feed on two species of mites, the nymphs of a whitefly species, and the larvae of an agromyzid fly. Also in Europe, F. megalops has been used for thrips control on trees in "internal landscapes" although not in commercial glasshouses (A. Loomans, pers comm. 2004). Ramakers et al. (2000), investigating the biological control of Echinothrips americanus on peppers in greenhouses, experimented both with the unisexual species F. vespiformis and a bisexual species, "Franklinothrips sp". This latter species was subsequently identified as $F$. orizabensis, a species that had been introduced commercially from California (Vierbergen, pers comm. 2004).

\section{Objectives}

The objective of this paper is to provide a means of recognising the 14 Franklinothrips species, including two new species described below, one from Nepal and one from New Caledonia. Of the 14, six are Neotropical, two Afrotropical, three Oriental, and three Australasian. A single female of a further species, from an unspecified locality in Malaysia, is present in the collections of the Natural History Museum, London, and this species will track in the key below to the couplet that includes $F$. atlas and $F$. fulgidus. Three species ( $F$. megalops, F. rarosae, F. variegatus) probably represent a cline across the Old World tropics between Africa and Australia, and are distinguished from each other on particularly weak character states. Two species, F. caballeroi from Central America and F. suzukii from Taiwan, cannot at present be distinguished satisfactorily, and it is possible that they represent a single species that has been distributed by the horticultural trade. Three Neotropical species are closely related, F. orizabensis, F. tenuicornis and $F$. vespiformis, the latter now being widespread around the world as a unisexual strain and here recorded from Australia for the first time. 
ANIC - Australian National Insect Collection, CSIRO Entomology, Canberra, Australia. BMNH - Natural History Museum, Cromwell Road, London SW7 5BD, England. MNHM - Muséum National d'Histoire Naturelle, Paris, France.

SMF - Forschungs-Institut Senckenberg, Senckenberg-Anlage 25, D-60325 Frankfurt am Main, Germany.

USNM - United States National Museum of Natural History, Washington DC, USA.

\section{Acknowledgements}

The authors are grateful to Richard zur Strassen at Frankfurt, and to Sueo Nakahara \& Dave Nickle at USDA, Beltsville, for help and encouragement during visits (by LAM) to the collections for which they are responsible, also to Shuji Okajima at Tokyo for loaning specimens of F. suzukii, and to Cecilia Reyes at Manila for providing information concerning F. rarosae. Mark Hoddle and Shuji Okajima helped improve the manuscript. And information about the use of these thrips in the Netherlands was kindly provided by Antoon Loomans, Bert Vierbergen, and Pierre Ramakers. CSIRO Entomology provided research facilities for LAM and the French Ministry of Agriculture for PR. Figures 1 and 2 of living thrips were kindly made available by Prof. Dr. Urs Wyss, Kiel University, Germany.

\section{Franklinothrips Back}

Franklinothrips Back, 1912: 75. Type species Aeolothrips vespiformis Crawford Mitothrips Trybom, 1912: 146. Type species Mitothrips megalops Trybom Spathiothrips Richter, 1928: 32. Type species S. bischoffi Richter (= F. megalops)

Generic diagnosis: Macropterous, sexually dimorphic, dark-bodied species. Female with abdominal segments I \& II more or less constricted and sometimes sharply pale, thus producing an ant-like body outline. Antennal segments III-IV exceptionally long and slender, III at least 8 times as long as wide and with elongate and sinuous or multifacetted sensoria. Head without long setae, usually partially retracted into prothorax and slightly prolonged in front of eyes; fore ocellus small, about half diameter of hind ocelli; compound eyes prolonged ventrally with enlarged posterior ommatidia; maxillary palps 3-segmented, segment III short. Pronotum with no long setae, posterior margin with stout transverse apodeme. Mesonotum usually with no sculpture on anterior half, with one pair of dominant setae medially. Metanotum without sculpture medially, with one pair of setae at anterior and one pair posteromedially. Forewings slender, costal margin with cilia but no setae; 
clavus usually with 5 (range 4-7) marginal setae. Fore tarsus with strongly recurved ventral hamus. Abdominal segment I constricted; tergites III-VI with median setal pair small and wide apart; sternites with two pairs of setae close to posterior margin and one or two pairs of discal setae laterally (these probably represent migrated posteromarginal setae); sternite VII with two pairs of accessory setae submedially; paired trichobothria on tergite $\mathrm{X}$ small. Male smaller than female, abdomen slender, wings usually paler, tergite I with pair of longitudinal ridges terminating in square or rounded apex overhanging tergite II.

Comments: The species in this genus are particularly uniform in the details of their body sculpture and chaetotaxy. The differences between species are related primarily to the degree of ant-mimicry exhibited (see habitus photographs Figs 3-17), including the colour of the forewings, abdomen, and basal antennal segments, the extent to which the first abdominal segment is constricted, and the extent to which the head is recessed into the prothorax. This latter character state is particularly difficult to assess, because although in the living insect the head may be withdrawn into the prothorax, the process of slidemounting commonly changes the orientation of the head to the pronotum, as mentioned below under $F$. variegatus (cf. original illustration of $F$. suzukii Okajima and Fig. 19). Stannard (1952) provided an extensive account of the genus, with a key to the six species then known. Mound \& Marullo (1996) provided a brief diagnosis and key to the six Neotropical species, although the character state involving the colour of antennal segment IV that is used, in part, to distinguish $F$. orizabensis from $F$. vespiformis is clearly incorrect. Since 1996, three further species have become available, F. basseti from Australia and two new species described below.

Generic relationships: The monobasic genus Corynothripoides Bagnall from Africa is the only genus that is closely related to Franklinothrips, differing in the greater pre-ocular prolongation of the head, but with the metanotum and the chaetotaxy of the abdominal sternites essentially similar. The only known species, C. marginipennis Bagnall, has the head strongly prolonged in front of the eyes, and the first ocellus either absent or reduced even more than in Franklinothrips brunneicornis (Figs 18, 20). The forewing longitudinal veins are widely separated, each unusually close to a wing margin, but this is also true of $F$. lineatus (Fig. 6). Should further material become available for study, Corynothripoides might need to be considered as a synonym of Franklinothrips. Antennal segments III and IV are yellow in C. marginipennis, with sensoria essentially similar to those of Franklinothrips species, and the forewing has the anterior and posterior margins dark with a median longitudinal pale area much as in F. lineatus (Fig. 6). The holotype female (in BMNH) was collected in Sierra Leone. The only other known specimens [in SMF] are two females from Rwanda and one female from Zaire. One male from Uganda with antennal segment III dark not yellow is probably this species, because similar sexual dimorphism is known in Franklinothrips. Nothing is known of the biology of $C$. marginipennis, although it is likely to be a predator of other thrips on the leaves of forest trees. 
1. Forewing shaded but not banded, with or without longitudinal pale areas (Figs 21-22).

. Forewing transversely banded with alternating dark and pale markings (Figs 24-27)...5

2. Antennal segments all dark brown; forewing dark but costal area pale in basal half (Fig. 22) brunneicornis

-. Antennae with at least segment III yellow 3

3. Forewing uniformly shaded without defined pale areas (Fig. 21) [Australia]....... basseti

-. Forewing with longitudinal pale area 4

4. Forewing with margins dark but median longitudinal pale area; antennal segment III yellow, but IV yellow medially with base and apex brown [Brazil] .. lineatus

-. Forewing dark along posterior half but costal area pale distally (Fig. 23); antennal segments III-IV clear yellow [Nepal].... strasseni

5. Abdominal segment $X$ dark, as dark as or darker than preceding segments (Fig. 8) ..... 6

-. Abdominal segment $X$ paler than preceding segments (Fig. 10) ...................................... 9

6. Abdominal segments uniformly dark .......................................................................... 7

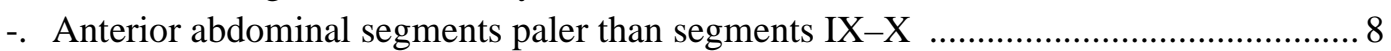

7. Antennal segment IV clear yellow [Taiwan] ...................................................... suzukii

-. Antennal segment IV yellow but shaded brown in distal third [Mexico, Costa Rica] ..... caballeroi

8 Head twice as wide as long, deeply recessed into and forming single outline with prothorax (Fig. 3); forewing median pale area about half as long as sub-basal dark area; antennal segments I-III yellow, IV brown [Africa].............................................. atlas

-. Head about as wide as long, distinct from prothorax (Fig. 8); forewing median pale area as long as sub-basal dark area; antennal segment I brown, II brown in basal half, III yellow, IV shaded distally but yellow near base [Brazil] ......................................... fulgidus

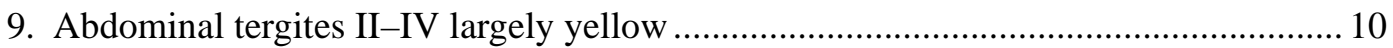

-. Abdominal tergite IV uniformly dark brown in contrast to yellow II-III .................... 11

10. Antennal segment IV clear yellow or shaded at extreme apex, antennal segment I yellowish brown to light brown (Fig. 15) [Australia] variegatus

-. Antennal segment IV with shaded area at apex a little longer than width of this segment, antennal segment I brown [Philipinnes] rarosae

-. Antennal segment IV with shaded area at apex distinctly longer than width of this segment, antennal segment I yellow; head nearly twice as wide as long, recessed into prothorax (Fig. 9) [Africa, India] megalops

11.Antennal segment IV yellow to light brown, distinctly paler than V (Fig. 13)... tenuicornis

-. Antennal segment IV dark brown, scarcely paler than V ....................................... 12

12.Forewing brown in distal half, without subapical pale area; maximum distal width of forewing at least 3.1 times width of hind tibia (Fig. 10, 24). orizabensis

-. Forewing with small subapical pale area, although this is sometimes indistinct; maximum distal width of forewing at most 2.9 times width of hind tibia (Fig. 16, 25).

vespiformis 

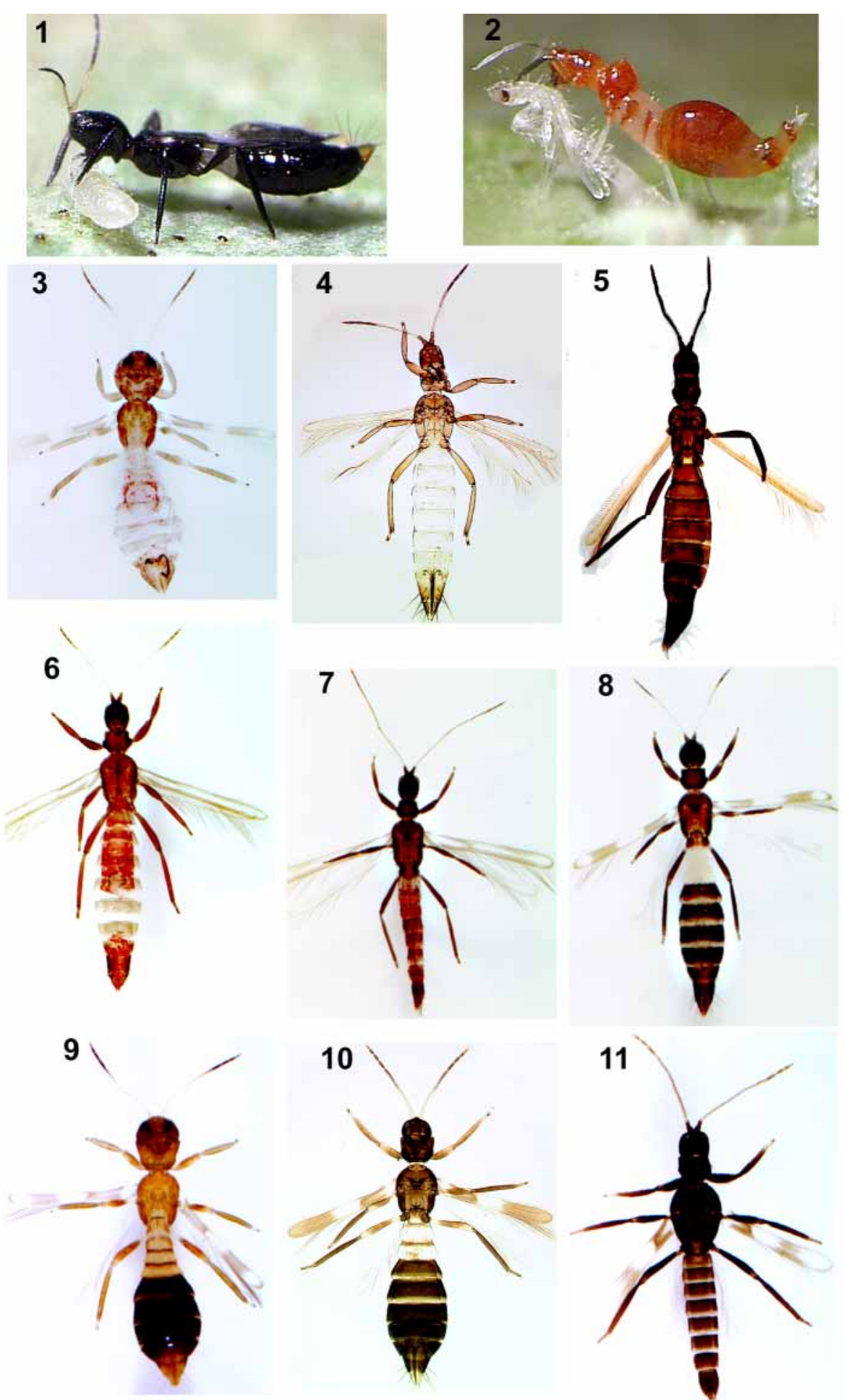

FIGURES 1-11. Franklinothrips species: (1) F. vespiformis female; (2) F. vespiformis larva; (3) F. atlas, female holotype; (4) F. basseti, female holotype; (5) F. brunneicornis, female holotype; (6) F. lineatus, topotypic female; (7) F. lineatus, topotypic male; (8) F. fulgidus, female holotype; (9) F. megalops, female from India; (10) F. orizabensis, female from California; (11) F. orizabensis, male from California. 
Described from a single female taken in the eastern Congo [USNM], four females have subsequently been studied from Rwanda [SMF]. The head is deeply recessed into the prothorax, resulting in a single compact spherical outline that is sharply constricted to the basal neck (Fig. 3). Unlike F. megalops, the tenth abdominal segment is not sharply paler than the ninth segment.
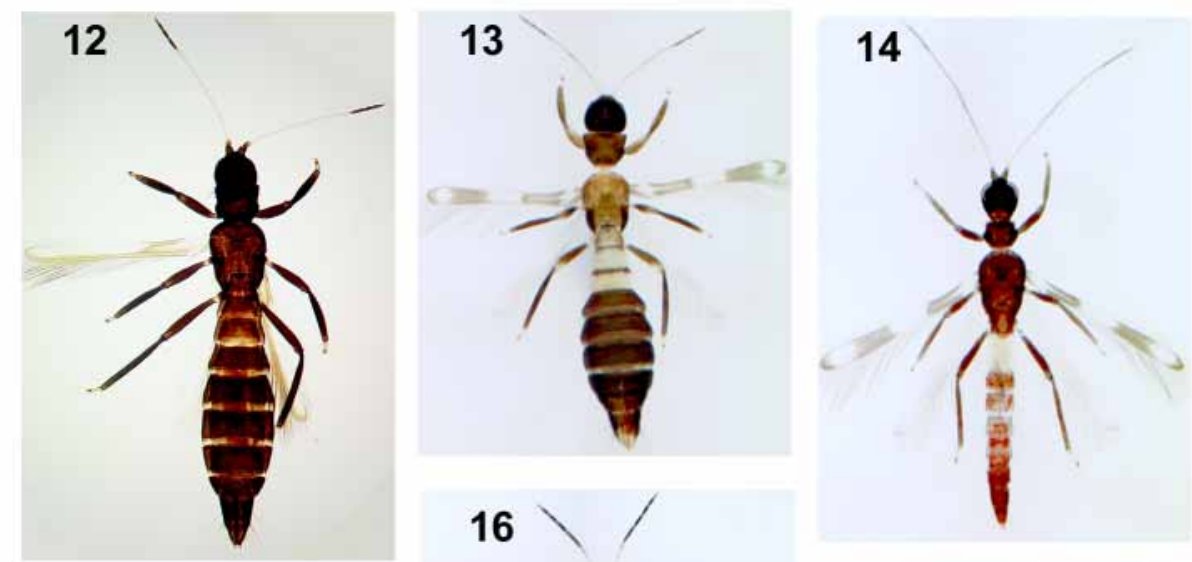

16
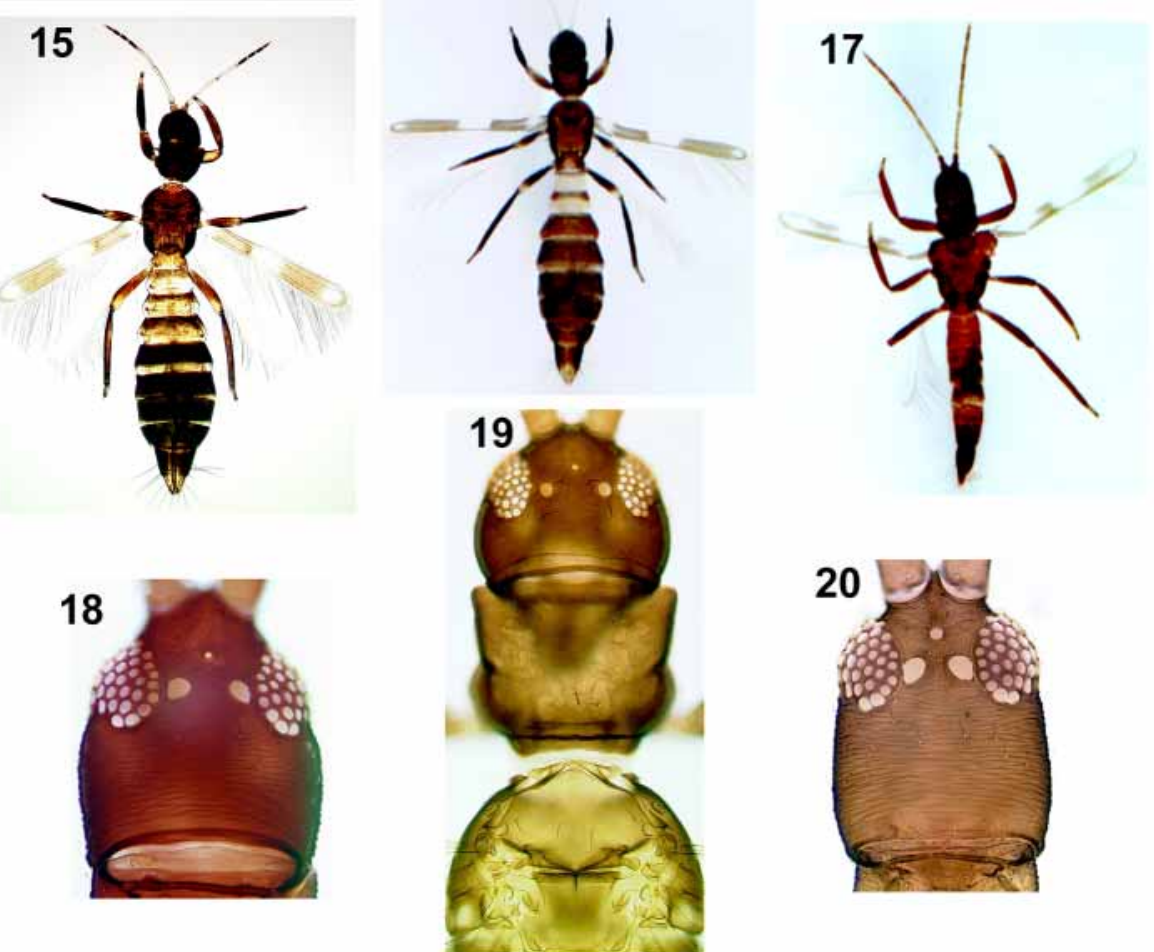

FIGURES 12-20. Franklinothrips species: (12) F. strasseni, female holotype; (13) F. tenuicornis, female from Sta Catarina, Brazil; (14) F. tenuicornis, male from Sta Catarina, Brazil; (15) F. variegatus, female; (16) $F$. vespiformis, female from Sao Paulo, Brazil; (17) F. vespiformis, male from Sedona, Arizona, USA; (18) $F$. brunneicornis, female head; (19) F. suzukii, female holotype; (20) F. brunneicornis, male head. 
The two females from which this species is known were taken from rainforest trees near Brisbane, Queensland, Australia [ANIC]. In body form it is one of the less well-developed ant-mimics in this genus, with uniformly dusky forewings (Fig. 21), and the abdomen brown and scarcely constricted at the base (Fig. 4).
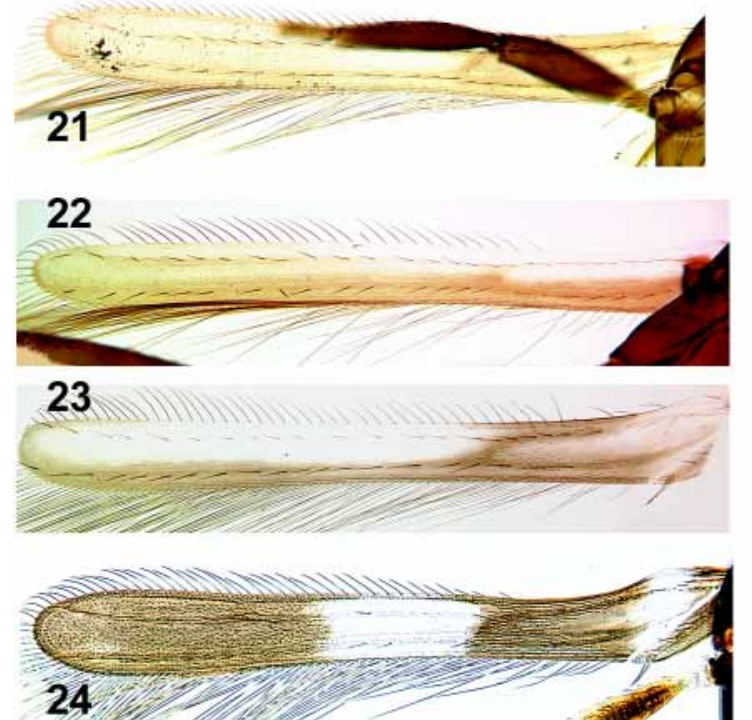

24
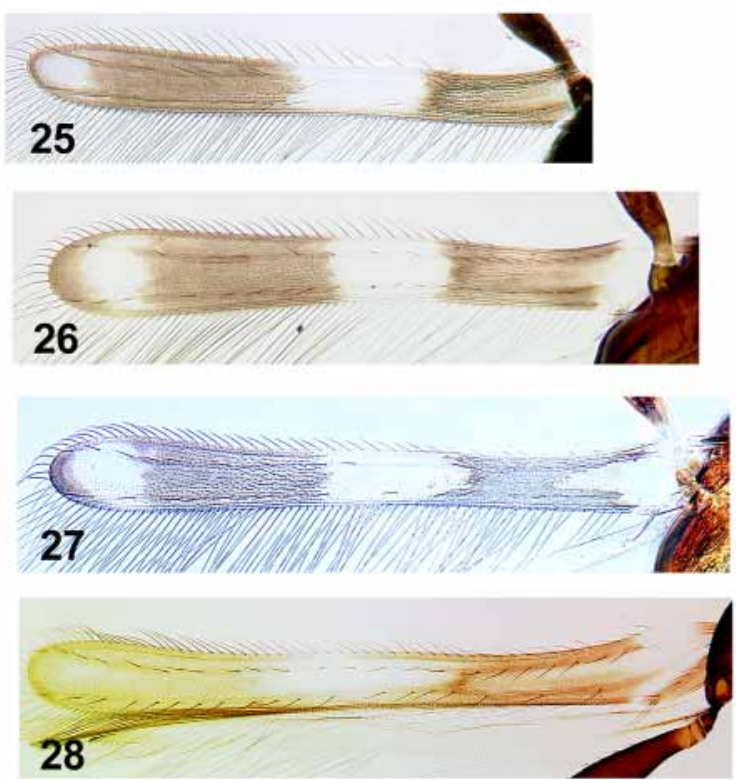

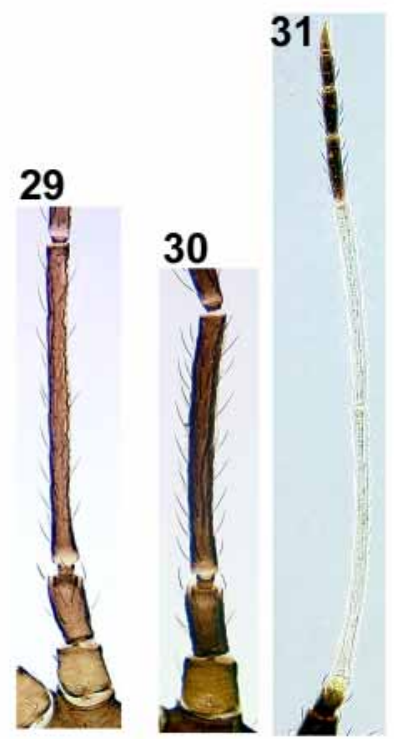

32

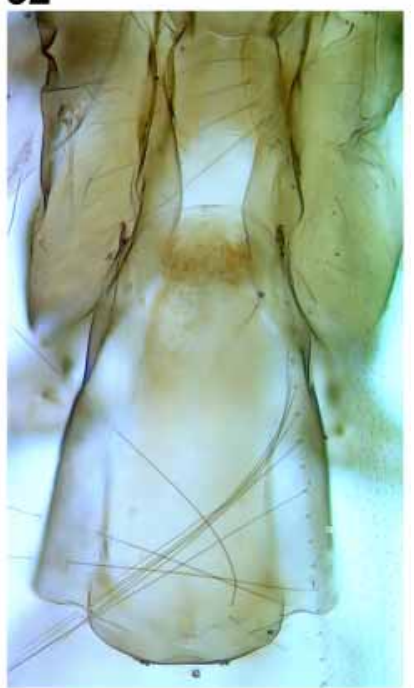

FIGURES 21-32. Franklinothrips species: 21-28 forewing; (21) F. basseti; (22) F. brunneicornis; (23) F. strasseni; (24) F. orizabensis; (25) F. vespiformis; (26) F. variegatus; (27) F. megalops; (28) F. suzukii; (29) F. brunneicornis, male antennal segments I-III; (30) F. brunneicornis, female antennal segments I-III; (31) F. strasseni, female antenna; (32) F. brunneicornis, male tergite I. 
Holotype female: New Caledonia, Pic d'Amoa, $\mathrm{N}$ slopes (alt. 500 m.) in Malaise trap, 1014.xi.2001 (Burwell C \& Monteith G); 2058'S 165¹7'E. Slide 8683 [MNHM].

Paratype male: New Caledonia, NinguaRes. Camp (alt. 1100 m.) in Malaise trap, 13-

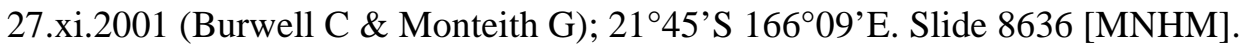

Female: Body and legs including tarsi dark brown (several legs missing on holotype, see Fig. 5); antennal segments I-IX brown; III and IV with a basal ring paler (Fig. 30). Forewing dark, without transverse pale area but with a pale costal area in basal half (Fig. 22).

Head longer than wide, not recessed into pronotum and strongly extended in front of eyes (Fig. 18); diameter of posterior ocelli three times that of fore ocellus; vertex with 4-5 pairs of postocular setae, median pair as long as posterior ocellus; maxillary palp II 3 times longer than III. Antennal segments III and IV with sensorium extending almost full length of segment. Transverse apodeme near pronotal posterior margin not visible in holotype; mesonotum with weak transverse striation; mesosternum entirely divided by furcal spinula. Forewing slender, clavus with 4-7 marginal setae. Abdominal tergite I narrow; tergal median setae small and wide apart; tergite IX twice length of VIII.

Measurements (holotype female in microns). Body length 2460. Head length 230; width 210; median postocular setae 30. Pronotum length 240; width 220. Forewing length 1320; median width 110. Antennal segments I-IX length: 45, 55, 225, 170, 80, 60, 50, 40, 20.

Male: Similar to female in colour and structure but paler and more slender. Tarsi and legs brown; head, abdomen and tergite I dark, tergites II to VI paler, VII to X gradually darker. Head prolonged in front of eyes, diameter of posterior ocelli twice that of fore ocellus (Fig. 20); antennae relatively longer than those of female (Fig. 29), segment III notably longer, sensorium extending entire length of III and IV; mesonotum with weak transverse striation on anterior half; posterior margin of tergite I with a short circular process above tergite II (Fig. 32). Setae S1 and S2 on tergite IX weakly developed, much shorter than those on X.

Measurements (paratype male in microns). Body length 2110. Head length 220; width 180; median postocular setae 20. Pronotum length 170; width 170. Forewing length 1200 ; median width 140. Antennal segments I-IX length: 40, 55, 280, 170, 100, 90, 70, 50, 15.

Comments: F. brunneicornis is one of the least ant-like species of the genus. It is unique in the genus in having entirely dark antennae, and the forewing is distinctive in colour, without pale transverse bands. This species is close to F. bassetti in having the forewing largely shaded, and the head relatively long with the first ocellus reduced. The structure of the head and reduced fore ocellus approach that of Corynothripoides marginipennis, suggesting that this genus might well be considered synonymous with Franklinothrips. 
Described from two females and one male taken in Veracruz, Mexico, a further seven females and one male were recorded from Costa Rica by Mound \& Marullo (1996). Although never compared directly, F. caballeroi is apparently similar to F. suzukii, based on two females from Taiwan, the distal part of antennal segment IV being lightly shaded in the former but clear yellow in the latter. Given the extensive horticultural trade involving Taiwan and parts of Central America, particularly but not exclusively in Orchidaceae, the possibility exists that these two names may represent the same insect species.

\section{Franklinothrips fulgidus Hood, 1949: 8}

This species is known only from specimens taken in southern Brazil (Fig. 8), between Rio de Janeiro and Santa Caterina State [USNM, BMNH].

\section{Franklinothrips lineatus Hood, 1949: 4}

Collected in considerable numbers in Santa Caterina State, southern Brazil (Fig. 6), mainly from Dalbergia [USNM], one female of this species has been studied from Costa Rica [BMNH].

\section{Franklinothrips megalops Trybom, 1912: 147}

Described originally from Kenya in the synonymic genus Mitothrips, the following three species are considered synonymous: F. aureus Moulton from South Africa, F. bischoffi Richter from Tanzania, and F. myrmicaeformis Zanon from Libya (Pitkin \& Mound, 1973; zur Strassen, 2003). This insect was observed commonly on trees in the gardens of the National Museum, Nairobi during August 1986. The females were not immediately recognised as Thysanoptera but, due to their behaviour, were considered initially to be bethylid wasps. They were noted to run actively, between periods of palpating the leaf surface with their antennae. The species is widespread in Africa, and specimens [SMF, BMNH] have been seen from the following countries: Spain, Israel, Palestine, Libya, Tunisia, Yemen, Somalia, Kenya, Uganda, Rwanda, Tanzania, Transvaal, South Africa, Mozambique, Angola, Nigeria and southern India. As noted below, F. megalops appears to be part of a cline across the Old World tropics that includes F. rarosae in the Philippines and F. variegatus in Australia, and the variation amongst museum specimens in the relationship of the head to the pronotum (Fig. 9) is mentioned below under F. variegatus. 
Described from Mexico, this species is common in southern California. It has been the subject of extensive study, on its ant-mimicry (Johansen 1983), and on its predatory behaviour (Hoddle, 2003a,b). It is a useful predator of a pest thrips on avocado trees in southern California (Hoddle et al., 2000), and has been evaluated as a potential biocontrol agent (Hoddle et al., 2001a,b, 2004). Moreover, as indicated in the Introduction above it has been marketed in Europe as a biocontrol agent against thrips in greenhouses. Judging from the records given by Johansen (1983), and from personal experience in Costa Rica, this bisexual species usually occurs on the leaves of shrubs and trees, in contrast to the closely related and essentially unisexual species, F. vespiformis. Females have the forewings uniformly dark near the apex without a subapical pale area (Fig. 10), and the wing apex is considerably broader than that of $F$. vespiformis. The forewings of males are much paler (Fig. 11).

\section{Franklinothrips rarosae Reyes, 1994: 129}

Known only from two males and one female, the holotype of this species is a male whose description is thus not comparable to the other species in this genus. It was not possible to borrow the female paratype for study, but Dr Cecilia Reyes has informed the authors that this female has the tenth abdominal segment paler than the preceding segments, and that antennal segment IV is yellow with the apical brown area a little longer than wide. This species is thus presumably intermediate between F. megalops and $F$. variegatus, and these three appear to be part of a cline across the Old World tropics from Africa to Australia.

\section{Franklinothrips strasseni sp.n.}

Holotype female: Nepal, Kathmandu, 12.iv.1976 (Baroni-Urbani \& Wittmer) [Naturhistorisches Museum Basel]

Female: Body and legs dark brown, tarsi yellow (Fig. 12); antennal segments III-IV clear yellow, remaining antennal segments brown; forewing pale at base anterior to second vein but with posterior area and jugal lobe shaded, a transverse dark band extends to first cross vein then the wing is dark posterior to second vein, extreme apex dark including apical ring vein (Fig. 23).

Head wider than long, cheeks rounded and recessed into prothorax, prolonged in front of eyes; diameter of posterior ocelli twice that of fore ocellus; vertex with 4 pairs of postocular setae, median pair longer than posterior ocellus; maxillary palp II 3.5 times longer than III. Antennae long (Fig. 31), segments III and IV with sensorium extending almost full length of segment. Pronotal posterior margin with stout transverse apodeme. Forewing 
clavus with 5 marginal setae. Abdominal tergite I narrow; tergal median setae small and wide apart; tergites VIII and IX subequal in length.

Measurements (holotype ㅇ in microns)

Body length 3010. Head, length 260; width 330. Pronotum, length 250; width 350. Forewing, length 1500; maximum distal width 150. Antennal segments I-IX length: 50, 55, 480, 330, 100, 70, 50, 30, 15.

Comments: The head and pronotum of this species are similar to that of F. suzukii (Fig. 19), but antennal segment III is particularly elongate (Fig. 31), being almost one third as long as the forewing. The abdomen is uniformly dark (Fig. 12), but is more constricted basally than in F. basseti and F. lineatus. As a result, the body form is intermediate between these more generalised species that are similar to Corynothripoides, and the more extreme ant mimicking species.

\section{Franklinothrips suzukii Okajima, 1979: 399}

The original two females of this species from Taiwan were examined, through the courtesy of Dr Shuji Okajima. However, it was not possible to arrange to compare these directly with specimens of $F$. caballeroi at the same time. As indicated above, these two species described from opposite sides of the world are similar in colour and structure. They may represent a single species whose disjunct distribution results from the horticultural trade. In life, the head of this species is recessed into the pronotum (see fig. in Okajima, 1979), but the slide mounting procedure results in a changed appearance (Fig. 19).

\section{Franklinothrips tenuicornis Hood, 1915: 163}

Described from Panama, with the synonym Mitothrips petulans Bagnall based on a male from Trinidad, this species has been studied from Trinidad, Surinam, Venezuela, Ecuador, Paraguay, Peru, and southern Brazil [SMF, BMNH, USNM]. Many of these specimens were taken from vines, including Vitex and Ipomoea, but others were taken from dead branches. The forewing pattern is similar to that of $F$. vespiformis, but antennal segment IV is paler than in that species, sometimes being largely yellow (Fig. 13).

\section{Franklinothrips variegatus Girault, 1927: 1}

Described originally from south eastern Queensland, Australia, this species (Fig. 15) has been found breeding at Canberra on the leaves of Catalpa in the Australian National University grounds, and also on Dodonaea shrubs at Mutawindji in western New South Wales. A single female has also been studied from the far north of Western Australia, near Drys- 
dale River NP. It probably represents a south eastern extension of the range of the common African species, F. megalops, and F. rarosae from the Philippines is presumably also related. The degree to which the outline of the head is confluent with that of the pronotum varies greatly between specimens in museum collections, and presumably depends on how extended the cervical membranes become during the chemical treatment involved in microslide preparation. Moreover, the length of the postocellar setae is variable in F. variegatus and F. megalops, both within and between locality samples.

\section{Franklinothrips vespiformis Crawford DL, 1909: 109}

Details of the biology of this species are given by Araraki and Okajima (1998), including the oviposition behaviour and the production of a silken pupation cocoon by the larvae. Although presumably native originally to Central America, females of this species have been found in many tropical countries. Specimens (BMNH, USNM) have been seen from: USA (Arizona, California, Texas, Florida), Bermuda, Puerto Rico, Cuba, Jamaica, St Vincent, Grenadines, Guadeloupe, Dominican Republic, Martinique, Barbados, Antigua, Trinidad, Mexico, Nicaragua, Honduras, Costa Rica, Panama, Colombia, Surinam, Venezuela, El Salvador, Brazil, Fiji, Japan, Thailand, New Caledonia, and Australia (Queensland). The Australian specimens were taken at Port Douglas in northern Queensland from lowgrowing weeds in an abandoned garden. This species (Figs 16,17) seems to prefer relatively low herbage, in contrast to the related species, F. orizabensis, that is usually associated with the leaves of trees. There are only two males labelled as $F$. vespiformis in the collections of USNM, Washington, and none in the BMNH, and a rearing programme involving this species at the Netherlands Plant Protection Department produced many females but only six males (pers comm. Bert Vierbergen, 2004). In contrast, males of $F$. tenuicornis, $F$. orizabensis and $F$. variegatus are commonly collected. The record of males of F. vespiformis in Brazil (Moulton, 1932) requires confirmation as the species referred to may have been $F$. orizabensis.

\section{References}

Araraki, N. \& Okajima, S. (1998) Notes on the biology and morphology of a predatory thrips, Franklinothrips vespiformis (Crawford) (Thysanoptera: Aeolothripidae): first record from Japan. Entomological Science, 1, 359-363.

Back, E.A. (1912) Notes on Florida Thysanoptera, with description of a new genus. Entomological News, 23, 73-77.

Bhatti, J.S. (1990) Catalogue of Insects of the Order Terebrantia from the Indian Subregion. Zoology (Journal of Pure and Applied Zoology), 2, 205-352.

Bournier, A., Lacasa, A. \& Pivot, Y. (1978) Biologie d'un prédateur Aeolothrips intermedius (Thys.: Aeolothripidae). Entomophaga, 23, 403-410.

Bournier, A., Lacasa, A. \& Pivot, Y. (1979) Régime alimentaire d'un thrips prédateur Aeolothrips 
intermedius (Thys.: Aeolothripidae). Entomophaga, 24, 353-361.

Crawford, D.L. (1909) Some Thysanoptera of Mexico and the South, I. Pomona College Journal of Entomology, 1, 109-119.

Girault, A.A. (1927) New Australian animals so far overlooked by outsiders. 2pp. Published Privately, Brisbane.

Hoddle, M.S. (2003a) Predation behaviours of Franklinothrips orizabensis (Thysanoptera: Aeolothripidae) towards Scirtothrips perseae and Heliothrips haemorroidalis (Thysanoptera: Thripidae). Biological Control, 27, 323-328.

Hoddle, M.S. (2003b) The effect of prey species and environmental complexity on the functional response of Franklinothrips orizabensis: a test of the fractal foraging model. Ecological Entomology, 28, 309-318.

Hoddle, M.S., Robinson, L., Drescher, K. \& Jones, J. (2000) Developmental and Reproductive Biology of a Predatory Franklinothrips n. sp. (Thysanoptera: Aeolothripidae). Biological Control, 18, 27-38.

Hoddle, M.S., Oishi, K. \& Morgan, D. (2001a) Pupation biology of Franklinothrips orizabensis (Thysanoptera: Aeolothripidae) and harvesting and shipping of this predator. Florida Entomologist, 84, 272-281.

Hoddle, M.S., Jones, J., Oishi, K., Morgan, D. \& Robinson, L. (2001b) Evaluation of diets for the development and reproduction of Franklinothrips orizabensis (Thysanoptera: Aeolothripidae). Bulletin of Entomological Research, 91, 273-280.

Hoddle, M.S., Oevering, P., Philips, P.A. \& Faber, B.A. (2004) Evaluation of augmentative releases of Franklinothrips orizabensis for control of Scirtothrips perseae in California avocado orchards. Biological Control, 30, 456-465.

Hood, JD. (1915) On some American Aeolothripidae (Thysanoptera). Entomological News, 26, $162-166$.

Hood, J.D. (1949) Brasilian Thysanoptera I. Revista de Entomologia, 20, 3-88.

Hood, J.D. (1957) Two new Thysanoptera from the Belgian Congo. Proceedings of the Royal entomological Society of London B, 26, 172-174.

Johansen, R.M. (1974) Siete nuevos Tisanopteros de Tabasco, Veracruz y el Pedregal de San Angel, Mexico, D.F. Thysanoptera: Terebrantia; Tubulifera). Revista de la Sociedad Mexicana de Historia Natural, 35, 249-276.

Johansen, R.M. (1979) Una nueva especies Mexicana de Frankliniella Karny (Thysanoptera: Thripidae), de la Sierra Madre Oriental. IV. Anales del Instituto de Biologia. Universidad Nacional de Mexico, 48 [1977], 71-76.

Johansen, R.M. (1983) Nuevos estudios acerca del mimetismo en el genero Franklinothrips Back (Insect: Thysanoptera) en Mexico. Anales del Instituto de Biologia. Universidad Nacional de Mexico, 53 [1982], 133-156.

Loomans, A.J.M. \& Heijboer, A. (1999) Franklinothrips vespiformis (Crawford): a polyphagous predator preying on thrips eggs. Proceedings of the section Experimental and Applied Entomology of the Netherlands Entomological Society (N.E.V.), 10, 143-150.

Loomans, A.J.M. \& Vierbergen, G. (1999) Franklinothrips: perspectives for greenhouse pest control. Bulletin IOBC/WPRS,22(1), 157-190.

Moulton, D. (1932) The Thysanoptera of South America I. Revista de Entomologia, 2, 451-484.

Mound, L.A. (2002) So many thrips - so few tospoviruses? Pp. 15-18 in Marullo, R. \& Mound, L.A. (eds) Thrips and Tospoviruses: Proceedings of the $7^{\text {th }}$ International Symposium on Thysanoptera. Australian National Insect Collection, Canberra.

Mound, L.A. \& Marullo, R. (1996) The Thrips of Central and South America: An Introduction. Memoirs on Entomology, International, 6, 1-488.

Mound, L.A. \& Marullo, R. (1998) Biology and identification of Aeolothripidae (Thysanoptera) in Australia. Invertebrate Taxonomy, 12, 929-950. 
Okajima, S. (1979) Notes on the Thysanoptera from Southeast Asia V. A new species of the genus Franklinothrips Back (Aeolothripidae). Kontyu, 47, 399-401.

Pinent, S.M.J., Mound, L.A. \& Izzo, T.J. (2002) Ectoparasitism in thrips and its possible significance for tospovirus evolution. Pp. 273-276 in Marullo R \& Mound LA [eds] Thrips and Tospoviruses: Proceedings of the $7^{\text {th }}$ International Symposium on Thysanoptera. Australian National Insect Collection, Canberra.

Pitkin, B.R. \& Mound, L.A. (1973) A catalogue of West African Thysanoptera. Bulletin de l'Institut Fondamental de l'Afrique Noire, 35, 407-449.

Ramakers, P.M.J., van den Meiracker, R.A.F. \& Mulder, S. (2000) Predatory thrips as thrips predators. Mededelingen Faculteit Landbouwkundige en Toegepaste Biologische Wetenschappen, Universiteit Gent, 65(2a), 343-350.

Reyes, C.P. (1994) Thysanoptera (Hexapoda) of the Philippine Islands. Raffles Bulletin of Zoology, 42, 107-507.

Richter, W. (1928) Beitrag zur Kenntnis der Aeolothripiden (Thysanoptera). Deutsche Entomologische Zeitschrift, 1928, 29-37.

Stannard, L.J. (1952) Phylogenetic studies of Franklinothrips (Thysanoptera: Aeolothripidae). Journal of the Washington Academy of Sciences, 42, 14-23.

Trybom, F. (1912) Mitothrips, eine neue Physapoden-Gattung aus Britischen Ostafrika. Entomologisk Tidskrift, 33, 145-159.

Zegula, T., Segonca, C. \& Blaeser, P. (2003) Entwicklung, Reproduktion und Prädationsleistung von zwei Raubthrips-Arten Aeolothrips intermedius Bagnall und Franklinothrips vespiformis Crawford (Thysanoptera: Aeolothripidae) mit Ernährung zweier natürlicher Beutearten. Gesunde Pflanzen, 55, 169-174.

Zur Strassen, R. (2003) Die terebranten Thysanopteren Europas und des Mittelmeer-Gebietes. Die Tierwelt Deutschlands, 74, 1-277. 